Cunha is a volcanic cone with a crater lake at the summit, there has been no previous record of eruption during historical times. The island does, however, lie on the flanks of the Mid. Atlantic Ridge, which is a belt of crustal weakness extending from Jan Mayen Island, through Iceland and the Azores, southwards towards the Antarctic. The nature and extent of this submarine feature were investigated during the recent International Geophysical Year.

\section{Award by the Fleming Memorial Fund}

THE Trustees of the Fleming Memorial Fund for Medical Research have made their first grant. This is to the University of Oxford and amounts to $£ 48,000$ for the Sir William Dunn School of Pathology at Oxford, headed by Sir Howard Florey. The grant is in connexion with electron-microscopy work at the School, where the purification of penicillin was achieved and its clinical use made possible. Recently, too, cephalosporin $C$, a penicillin-like antibiotic active against some important penicillin-resistant bacteria, was discovered at the Sir William Dunn School of Pathology.

The Fleming Memorial Fund for Medical Research was launched in March this year in memory of Sir Alexander Fleming, discoverer of penicillin, to assist basic medical research. Its British and international appeal, with a target of $£ 1$ million, lasts until March 1962. So far more than $£ 370,000$ has been raised.

\section{New Thinking in School Chemistry}

Tre Office for Scientific and Technical Personnel of the Organization for European Economic Cooperation arranged a seminar held at Greystones, Co. Wicklow, during March 1960, to deal with the status and development of school chemistry teaching (see Nature, 186, 208; 1960), and the report has now been issued with the title "New Thinking in School Chemistry" (Pp. iii +215. Paris: Organization for European Economic Co-operation--Office for Scientific and Technical Personnel, 1961). The contributions and discussions show that there is considerable difference of opinion on some topics. Some favour a dogmatic theoretical treatment beginning with the atom and electron as familiar modern concepts and proceeding to the development of theories of structure and bonding, the teaching being largely centred on the periodic table. What one speaker calls 'stick-in-the-mud experiments' will not take a prominent place. It is felt that distinction of $s$ and $p$ orbitals might be too difficult. There is sharp dis. agreement among those favouring this approach as to the meaning of the theories, and teachers using this method will obviously need annual refresher courses. An American speaker states that in some schools there the teaching begins with organic chemistry. Other speakers, including two from the United States, explain schemes in which models to illustrate atomic linking and molecular structure are made by the pupils. Some think that this will take too much time and will be costly. Opinions are divided on the value of films. Another group of speakers favours an experimental approach and thinks that practical work is desirable. Qualitative and quantitative analysis can illustrate general chemistry and inculcate habits of neatness and accuracy. Some suggestions for new experiments, including the use of paper chromatography in qualitative anslysis, are made. Summaries of the discussions, three joint reports, and recommendations for future action close the proceedings.

\section{Radiation Botany}

THE first number of Radiation Botany, a new inter. national journal devoted to plant radiobiology and related subjects, was published in September. It is odited by A. H. Sparrow together with an editorial board drawn from seven countries (Radiation Botany, Vol. 1, No. 1; September 1961. Pp. 100. Annual subscription rates: $(A)$ for libraries, government establishments, research laboratories, etc., 140s., 20 dollars; $(B)$ for individuals who place their order directly with the publisher and certify that the journal is for their personal use, 70s., 10 dollars. London and New York: Pergamon Press, 1961). This first issue of a hundred pages consists of eleven scientific contributions the subject-matter of which includes, factors affecting responses of plants to radiation, root absorption of fission products derived from underground nuclear explosion, morphological responses to gamma-rays and the influence of radiation on chiasma frequency. These and other topics dealt with illustrate the main aim of the journal, which is to be concerned with the effects of ionizing radiations on plants. It will, however, also be devoted to the more technical aspects of plant irradiation. Each contribution is usefully prefaced by abstract. in English, French and German, and papers are acceptable in any of these languages.

The journal is attractively printed in a style in keeping with the modern nature of the subject. The choice of type, paper and general layout makes Radiation Botany a very readable journal. Table layout is particularly good, and the line illustrations and plates are of a high standard. Though all workers in the field of radiobiology will welcome this new outlet for their writings, one may hope that genetical and physiological journals will continue to receive contributions from those who have used radiations to elucidate problems primarily concerned with those sciences.

\section{Lanehead Field Centre}

THE increasing scientific interest being shown in the 'marginal land' of the British Isles is reflected in the recent foundation of a new research centre in the Northern Pennines. The Department of Geography of the University of Durham, under the guidance of Prof. W. B. Fisher, has recently acquired a village school at Lanehead, near Cowshill, in Upper Weardale, and has speedily converted the building into an active centre for field research. Situated near the watershed of the Rivers Tyne, Wear and Tees, the new centre dominates a virgin area for field and ecological investigations. Research projects have already been started on the geomorphology, microclimate, soils and vegetation of the region, and progress is being made in the analysis of the social life of the inhabitants of the Upper Pennine Dales. In addition to giving field courses to the undergraduates of the University of Durham, the research workers (mainly postgraduate students) hope to add, in some: way, to our knowledge of the social and environmental background for future development in highland Britain. Many aspects of the background still perplex the technologist and the economist; it is hoped that Lanehead Field Centre will provide at least some of the answers.

\section{Rutgers Center of Alcohol Studies}

THE Center of Alcohol Studies, which was instituted at Yale University in 1921, is being transferred to Rutgers, The State University, and will be known as 